\title{
No easy route of evolution for weapons labs, says OTA
}

\begin{abstract}
Washington. What is to happen to the atomic weapons laboratories in the United States now that the Cold War has ended? The best way forward for the laboratories, mostly controlled by the Department of Energy (DoE), would be for them to follow a broad spectrum of collaborative research aimed at improving US industrial competitiveness, according to a report prepared by the congressional Office of Technology Assessment (OTA).
\end{abstract}

OTA in particular insists that none of the laboratories could be adequately occupied by large individual programmes, such as the Clinton administration's plan to help develop a clean car. Such schemes, however ambitious, could occupy only a small proportion of the resources of the vast Lawrence Livermore, Los Alamos and Sandia national laboratories, which have a combined budget of $\$ 3.4$ billion and employ 24,000 people.

OTA's report comes at a time when several more pieces of legislation assigning new responsibilities to the laboratories have been launched in the Congress, and when uncertainty among members of the laboratories' scientific staffs is growing.

Bending the national laboratories to civil uses has been on the open agenda for several years. Several collaborations with industry are already under way. OTA now argues that the laboratories would be better placed to generate more work through cooperative research and development agreements (CRADAs) if the DoE were to speed up the process of authorizing them: on past form, it takes six months for an agreement to be approved. So OTA suggests that the department's bureaucracy should be streamlined, and pleads for a better understanding by Congress of how legislation, even in apparently unrelated fields, can impede the process.

Despite the virtual cessation of nuclear weapons development, Livermore, Los Alamos and Sandia are said to be still chiefly orientated towards other nuclear work, such as weapon maintenance and clean-up, says OTA senior associate Julie Gorte. "It has been horrendously difficult for industry to do collaborative research with the Department of Energy labs", she says.

Department of Energy laboratories have signed almost 400 CRADAs in the past two years, and within the department's Defense Programs division they have a budget of $\$ 141$ million. But that is still a small portion of the laboratories' total budgets.

OTA also suggests that Congress, when framing legislation, must make up its mind exactly what it wants to achieve in the exploitation of new knowledge arising from work at the national laboratories. At present, industrial collaborations are impeded by legal requirements that products emerging from collaborative work at the national laboratories should preferably be manufactured in the United States. Restrictions on the disposal of property rights are given as another cause of difficulty.

OTA points out that clauses binding collaborators to US manufacture, frequently inserted in US research legislation ( see $\mathrm{Na}$ ture 363, 481; 1993), will deter many participants and therefore reduce the prospects of saving jobs at the DoE laboratories. Similarly on intellectual property, a choice must be made between the wish to disseminate knowledge widely, on the one hand, and to attract partners who want to safeguard it for themselves, on the other.

The OTA report is published as bills

progress through Congress with the aim of providing a new mission for the DoE laboratories. The Laboratory Technology bill being discussed by Science, Space and Technology Committee in the House of Representatives and the Department of Energy National Competitiveness bill proposed by the Senate's Energy Committee are likely to be reconciled with each other and passed later this summer. They already include some of the changes suggested by the OTA, such as the delegation of the authorization of small collaborative projects directly to the laboratory directors.

The OTA examined two large initiatives which had been mooted as potential 'saviours' of the weapons laboratories - the development of clean cars and of hightechnology public transport systems -- and concluded that these or other such programmes could have only a limited impact.

Energy secretary Hazel O'Leary welcomed the OTA report and promises to "respond with vigour". "I have set several efforts in motion during the past few months to help put our technology transfer house in order," she says.

Colin Macilwain

\section{UK to close environmental research lab}

London. Scientific staff of Britain's main research centre for environmental technology, the Warren Spring Laboratory at Welwyn outside London, are trying to block the government's plans to merge the laboratory with AEA Technology in Oxfordshire, a move that is likely to lead to the loss of up to 150 jobs.

This move follows an announcement by Michael Heseltine, who as president of the board of trade is head of the Department of Trade and Industry (DTI) and thus the government minister responsible for both organizations, that they are to be combined into a single centre of excellence known as the National Environmental Technology Centre (NTEC).

Heseltine told Parliament last week that the goal of the merger is to combine the complementary strengths of the two organizations, ensuring a "more comprehensive service" for their customers and better value for taxpayers's money. AEA Technology already has a large group of researchers working on environmental issues.

But the Institution for Professionals, Managers and Specialists, the trade union representing more than 200 scientific staff at Warren Spring, argues that the merger is the direct result of the DTI's decision to reduce its spending on research. At risk, it says, are a number of important research projects, such as several into techniques for monitoring air pollution, which would not easily attract sponsorship from the private sector.

Union representatives have been promised a meeting with Heseltine this week to express their concern. They are planning to tell him that his decision contradicts a promise made to Parliament last month that the future of the DTI's five research laboratories would be decided only after the completion of a study into their future prospects by the consulting firm KPMG.

They are also planning to mount a legal challenge to the DTI's plans to transfer staff from Welwyn to AEA Technology, claiming that Heseltine lacks the authority to require such a move.

DTI officials deny that the decision on Warren Spring is premature, claiming that the merger does not amount to the closure of the laboratory - and that the KPMG survey will be used to assess whether the NTEC should be privatized (a path to which AEA Technology is already committed).

The move of research teams to Oxfordshire will, however, be a considerable embarrassment to the government. Only last year, the then trade minister Peter Lilley announced plans to erect a new building for the Warren Spring Laboratory in Welwyn, at a cost of $£ 25$ million. The site of the new building has already been prepared, at a cost of $£ 7$ million, and this money will have to be written off.

The government decision to merge the two laboratories has also been criticized by the opposition Labour party. Jim Cousins, the party spokesman on trade and industry, claimed last week that there will inevitably be tensions between an organization that has been devoted to research into ways of protecting the environment and another whose traditional role has been to promote the development and use of nuclear power.

David Dickson 